\title{
The Determinants of Traditional Health Care Use in the Era Health Insurance in Indonesia
}

\author{
Nurhayati ${ }^{1 *}$, Lucie Widowati $^{1}$, Hadi Siswoyo ${ }^{1}$, Delima ${ }^{1}$, Andi Leny Susyanty ${ }^{1}$ \\ ${ }^{1}$ Center for Research and Development of Health Resources and Service, National Institute of Health Research and \\ Development, Jakarta, Indonesia
}

\section{A R T I C L E I N F O}

\section{IAKMI IPHJI use only:}

Received date : 13 April 2020

Revised date : 29 April 2020

Accepted date : 2 June 2020

Keywords:

health insurance

national

health care

traditional

\begin{abstract}
A B S T R A C T
The use of traditional medicine has increased significantly over the past few years. The main reasons for the increasing use of traditional medicine is a growing trend for patients to take a more proactive approach to their own health and to seek out different forms of self-care. This study aimed to identify the dominant risk factors that related to use of traditional health care in the era health insurance in Indonesia. The study used household data from 2018 National Health Survey Indonesia. Using cox regression, we then could present dominant risk factors that related to use of traditional health care among Indonesian in the era health insurance. Total subjects had been analyzed were 764,996 subjects. The proportion of those who used of traditional health care were $31.4 \%$ $(337,471 / 764,996)$. Dominant risk factors related to used of traditional health care were gender, age group, employment status, knowing about the availability of health care, and Affordability of transportation costs to health care. Compared with those who were male, those were female had 1.09 more likely to used of traditional health care [odds ratio adjusted $(\mathrm{ORa})=1.09 ; 95 \% \mathrm{CI}=1.04$ to 1.14$]$. Household who had low education level had 1.10 more likely to used of traditional health care $(\mathrm{ORa}=1.10$; $95 \% \mathrm{CI}=1.03$ to 1.18 ). Household who were private employees had 1.33 more likely to used of traditional health care $(\mathrm{ORa}=1.33 ; 95 \% \mathrm{CI}=1.25$ to 1.41). Household who had high economic level had 1.31 more likely to used of traditional health care $(\mathrm{ORa}=1,31 ; 95 \% \mathrm{CI}=1,23$ to 1,41). Furthermore, household who knowed about the availability of health care had 1.44 more likely to used of traditional health care (ORa=1,44; $95 \%$ $\mathrm{CI}=1,29$ to 1,60$)$. Household subjects who were female, aged $46-65$ years old, self-employed workers, aware of the availability of health services, affordable for transportation costs to health facilities were more likely to use traditional health care.
\end{abstract}

(C) 2020 IAKMI Indonesian Public Health Journal. All rights reserved

\section{INTRODUCTION}

Traditional health services are one of the health efforts of the 17 health efforts stipulated in Law no. 36 of 2009 concerning health. Health efforts are carried out in the form of activities with promotive, preventive, curative and rehabilitative approaches that are carried out in an integrated, comprehensive and continuous manner [1]. Health services have so far been more dominant in treatment, where

\footnotetext{
* Corresponding author.

E-mail address: nurhayati.litbangkes@gmail.com
}

patients have more confidence in doctors with a medical system based on medical science that is officially adopted. With this condition, even distribution of health services cannot be fulfilled, because health services are still concentrated in big cities, while the majority of the population in Indonesia lives in rural areas with low incomes who actually need simple, cheap, effective, and affordable health services in accordance with their abilities [2].

Traditional health services have been regulated in PP 103 of 2014 on Traditional Health Services [3]. However, since the issuance of PP 103 in 2014, traditional health 
services have also been carried out by diploma or bachelor educated staff who have been regulated as health workers. The implementation of health efforts must be carried out by responsible health workers, with skills enhanced through education [4]. Diploma education in Surakarta and diploma Traditional Medicines in Surabaya has been running for several years and has produced graduates of health workers. In PP 103 of 2014, it is regulated that it is expected that seven years since the PP was issued, a traditional health higher education or S1 Traditional Indonesian Health (Kestraindo) has been formed, but the fact is that there are doctors who provide traditional medicine services at the health facility or clinic/practice personally, it is still considered as a transitional pathway for traditional medicine served by doctors to traditional health workers

The results of the herbal medicine research on herbal medicine in tumor/cancer patients, as a complementary therapy by doctors, of 71 tumor or cancer patients, 57 patients $(80.3 \%)$ received herbal therapy, 10 patients $(14.1 \%)$ received conventional therapy and herbal medicine, 2 patients (2.8\%) received conventional therapy, herbal medicine and skills (acupuncture), and 1 patient (1.4\%) received herbal therapy and acupuncture [5]. In Indonesia there are 32,725 health care facilities, traditional herbal health workers employed at the health facility totaling 67 and for skilled workers totaling 825 , bringing the total in all provinces to 892 health workers [6].

Base on final report of national basic health research 2013 (Riskesdas), there are around $30 \%$ of households that use traditional health Services [7]. There was a slight increase, the 2018 Riskesdas data stated that $31.4 \%$ of the population utilized traditional health services, the highest in South Kalimantan (54.1\%). However, of the $31.4 \%$ of people who use traditional health services, the choice of the community for traditional health workers is $98.5 \%$, while the choice of health workers has only reached $2.3 \%$ educated. This is related to the government's expectation that traditional health services must be safe, beneficial and of good quality. In addition to utilizing the tradisional medicine, there are people who make their own efforts. A total of
$12.9 \%$ made their own efforts, the highest in the Province of Bali at $23.6 \%$ [8].

But considering the traditional service choices by someone can depend among other things on geographical factors in this case for example; living in a village or city, how affordable or distance to service facilities are, how work is affected, economic status, ownership of the National Health Insurance and other factors that play an equally important role. An example is if the service personnel or facilities are located far enough away, how to reach the health facility, and socio-economic to ensure their health. Demographic factors will also affect the choice of traditional health services. This study aims to look at the dominant factor of community choice for traditional health services. Empirical and complementary in Indonesia in the era of health insurance.

\section{METHOD}

The design of this analysis is Cross sectional. The source of this analysis data is the Riskesdas 2018 data. The Riskesdas 2018 data collection was conducted in May-June 2018. The data came from a structured questionnaire divided into sociodemography (region, level of education of household heads, type of occupation of household heads), household economic status (quintile), access to health facilities (availability of health facilities) and travel time), ownership of health insurance, utilization and types of traditional health services.

The population analysis included households and individuals in Indonesia who utilized health services. The sample of the study was household members who used traditional health care. Samples were derived from data in 33 provinces and 514 districts/ cities. For public health data, a basic health data was collected from 300,000 household samples. The sampling method is adjusted to the 2018 Riskesdas sampling which follows the 2018 Susenas KOR respondents' sampling.

Sample selection for further analysis is done by taking samples that meet the inclusion and exclusion criteria. Inclusion criteria included household members at Riskesdas 2018 who answered in full on the questions or variables needed. The exclusion criteria are household members living in remote islands 
and household members where there are no health facilities in the area. The number of samples analyzed was 764,996 respondents.

Variables analyzed included the utilization of traditional health services, types of traditional health services by traditional sanitary/hattra, types of traditional health services by health workers/health workers, type of residential area (city and village), level of education of family heads, employment status of household heads, type of work the head of the family, expenditure quintile, availability of health facilities, travel time to health facilities, utilization of toga, health insurance ownership.

Data processing and analysis is done descriptively and analytically using a data processing program. Descriptive analysis includes an overview of the independent variables analytic analysis includes bivariate and multivariate analysis with multiple logistic regression analysis methods to determine the dominant factors associated with the utilization of traditional health services.

Ethical clearance was granted from the Research and Ethics Committee of National Institute for Health Research and Development, Ministry of Health.

\section{RESULTS AND DISCUSSION}

Table 1 showed that the proportion of subjects that used of traditional health care were $31.4 \%(337,471 / 764,996)$. Those who used of traditional health care and did not use of traditional health were differently distributed with respect to gender, age group, level of education, employment status, level of economic, have a national health insurance card, knowing about the availability of health care, and affordable for transportation costs to health facilities.

Table 2, the final model shows that gender, age group, employment status, knowing about the availability of health care, and Affordability of transportation costs to health care as dominant factors related to used of traditional health care. Compared with those who were male, those were female had 1.09 more likely to used of traditional health care. Household who had low education level had 1.10 more likely to used of traditional health care. Household who were privat employees had 1.33 more likely to used of traditional health care). Household who had high economic level had 1.31 more likely to used of traditional health care. Furthermore, household who knowed about the availability of health care had 1.44 more likely to used of traditional health care.

Table 1. Several characteristics and risk of use of traditional health care among Indonesian in the era health insurance.

\begin{tabular}{|c|c|c|c|c|c|c|c|}
\hline \multirow{3}{*}{ Variable } & \multicolumn{4}{|c|}{ Use of traditional health } & \multirow{3}{*}{$\begin{array}{l}\text { Crude } \\
\text { Odds } \\
\text { ratio }\end{array}$} & \multirow{3}{*}{$\begin{array}{l}\text { 95\% confidence } \\
\text { interval }\end{array}$} & \multirow[b]{2}{*}{$\mathrm{P}$} \\
\hline & \multicolumn{2}{|c|}{ Yes $(n=337,471)$} & \multicolumn{2}{|c|}{ No $(n=427,525)$} & & & \\
\hline & $n$ & \multicolumn{2}{|c|}{ Gender } & $\%$ & & & \\
\hline Female & 174500 & 45.3 & 210902 & 54.7 & 1.10 & $1.087-1.115$ & 0.001 \\
\hline Male & 162971 & 42.9 & 216623 & 57.1 & & Reference & \\
\hline \multicolumn{8}{|l|}{ Age groups (years) } \\
\hline$>65$ & 23595 & 53.4 & 20591 & 46.6 & 2.09 & $2.30-2.163$ & 0.001 \\
\hline $46-65$ & 95671 & 54.9 & 78562 & 45.1 & 2.27 & $2.223-2.309$ & 0.001 \\
\hline $26-45$ & 112231 & 48.8 & 117927 & 51.2 & 1.81 & $1.714-1.844$ & 0.001 \\
\hline$\leq 25$ & 105974 & 33.5 & 210445 & 66.5 & & Reference & \\
\hline \multicolumn{8}{|l|}{ Level of education } \\
\hline High & 23265 & 49.4 & 23863 & 50.6 & 1.21 & $1.17-1.25$ & 0.001 \\
\hline Middle & 118668 & 45.6 & 141381 & 54.4 & 1.04 & $1.02-1.06$ & 0.001 \\
\hline \multirow{2}{*}{\multicolumn{8}{|c|}{$\begin{array}{l}\text { Low } \\
\text { Occupation status }\end{array}$}} \\
\hline & & & & & & & \\
\hline Military/police/civil & 11234 & 50.9 & 10839 & 49.1 & 1.52 & $1.45-1.60$ & 0.001 \\
\hline Privat employees & 19504 & 47.2 & 21779 & 52.8 & 1.27 & $1.23-1.31$ & 0.329 \\
\hline Enterpreneur & 39092 & 51.5 & 36870 & 48.5 & 1.53 & $1.49-1.57$ & 0.001 \\
\hline Labor and other & 115741 & 50.8 & 112101 & 49.2 & 1.49 & $1.46-1.51$ & 0.028 \\
\hline Unemployed & 108160 & 40.6 & 158094 & 59.4 & & Reference & \\
\hline \multicolumn{8}{|l|}{ Econimic status } \\
\hline Quintiles 2 & 72555 & 43.6 & 93930 & 56.4 & 1.02 & $0.99-1.06$ & 0.001 \\
\hline Quintiles & 67999 & 44.2 & 65955 & 55.8 & 1.05 & & 0.001 \\
\hline Quintiles 4 & 63061 & 44.7 & 77861 & 55.3 & 1.07 & $1.04-1.12$ & 0.001 \\
\hline Quintiles 5 & 56253 & 45.7 & 66850 & 54.3 & 1.16 & $1.05-1.13$ & 0.001 \\
\hline Quintiles 1 & 77603 & 43.0 & 102928 & 57.0 & & Reference & \\
\hline \multicolumn{8}{|c|}{ have a national health insurance card } \\
\hline Yes & 65200 & 45.9 & 77032 & 54.1 & 1.07 & $1.05-1.10$ & 0.001 \\
\hline No & 272241 & 43.7 & 2500493 & 56.3 & & Reference & \\
\hline \multicolumn{8}{|c|}{ Knowing about the availability of health care } \\
\hline Available & 253159 & 45 & 309738 & 55.0 & 1.16 & $1.13-1.19$ & 0.001 \\
\hline Not available & 84271 & 41.7 & 117710 & 58.3 & & & \\
\hline \multicolumn{8}{|c|}{ Affordable for transportation costs to health facilities } \\
\hline & 325068 & 44.3 & 18711 & 60.1 & 1.34 & $1.26-1.42$ & 0.001 \\
\hline unaffordable & 12403 & 39.9 & 408814 & 55.7 & & Reference & \\
\hline
\end{tabular}

Table 2. Several dominant factors and risk of use of traditional health care among Indonesian in the era health insurance.

\begin{tabular}{|c|c|c|c|c|c|c|c|}
\hline \multirow[b]{2}{*}{ Variable } & \multicolumn{4}{|c|}{ Use of traditional health } & \multirow{2}{*}{$\begin{array}{l}\text { Adjusted } \\
\text { Odds } \\
\text { ratio }\end{array}$} & \multirow{2}{*}{$\begin{array}{l}95 \% \text { confidence } \\
\text { interval }\end{array}$} & \multirow[b]{2}{*}{$\mathrm{P}$} \\
\hline & Yes $(n=3$ & $\frac{7,471)}{\% 6}$ & No $(n=4$ & $\frac{7,525)}{\%}$ & & & \\
\hline \multicolumn{8}{|c|}{ 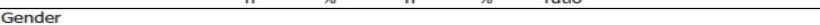 } \\
\hline $\begin{array}{l}\text { Female } \\
\text { Male }\end{array}$ & $\begin{array}{l}174500 \\
162971\end{array}$ & $\begin{array}{l}45.3 \\
42.9\end{array}$ & $\begin{array}{l}210902 \\
216623\end{array}$ & $\begin{array}{l}54.7 \\
57.1\end{array}$ & 1.186 & $\begin{array}{c}1.173-1.199 \\
\text { Reference }\end{array}$ & 0.001 \\
\hline \multicolumn{8}{|l|}{ Age groups (years) } \\
\hline$>65$ & 23595 & 53.4 & 20591 & 46.6 & 2.150 & $2.104-2.196$ & 0.001 \\
\hline $46-65$ & 95671 & 54.9 & 78562 & 45.1 & 2.169 & $2.137-2.203$ & \\
\hline $26-45$ & 112231 & 48.8 & 117927 & 51.2 & 1.691 & $1.667-1.715$ & \\
\hline$\leq 25$ & 105974 & 33.5 & 210445 & 66.5 & & Reference & \\
\hline \multicolumn{8}{|l|}{ Occupation status } \\
\hline Military/police/civil & 11234 & 50.9 & 10839 & 49.1 & 1.122 & $1.090-1.155$ & 0.001 \\
\hline Privat employees & 19504 & 47.2 & 21779 & 52.8 & 1.183 & $1.157-1.209$ & \\
\hline Enterpreneur & 39092 & 51.5 & 36870 & 48.5 & 1.230 & $1.208-1.252$ & \\
\hline Labor and other & 115741 & 50.8 & 112101 & 49.2 & 1.209 & $1.193-1.226$ & \\
\hline Unemployed & 108160 & 40.6 & 158094 & 59.4 & & Reference & \\
\hline \multicolumn{8}{|c|}{ Knowing about the availability of health care } \\
\hline Available & 253159 & 45 & 309738 & & 1.119 & $1.106-1.132$ & 0.001 \\
\hline Not available & 84271 & 41.7 & 117710 & & & Reference & \\
\hline \multicolumn{8}{|c|}{ Affordable for transportation costs to health facilities } \\
\hline & 325068 & 44.3 & 18711 & 60.1 & 1.141 & $1.111-1.172$ & 0.001 \\
\hline unaffordable & 12403 & 39.9 & 408814 & 55.7 & & Reference & \\
\hline
\end{tabular}

The purpose of study was to identify potential risk factors affecting use of traditional health care among Indonesian in the era health insurance. In developing countries, the affordability, availability, and cultural familiarity of traditional medicine, as well as family influences, contribute to the continued use of traditional medical providers and medicines.

Traditional and complementary medicine is widely used around the world and valued for a number of reasons. For many millions of 
people, herbal medicines, traditional treatments, and traditional practitioners are the main source of health care, and sometimes the only source of care. This is care that is close to homes, accessible and affordable. It is also culturally acceptable and trusted by large numbers of people. The affordability of most traditional medicines makes them all the more attractive at a time of soaring health-care costs and nearly universal austerity [9].

The widespread use of traditional medicine in Africa and some developing countries can be attributed to its being present on the ground and readily affordable. For instance, the ratio of traditional healers to population in Africa is 1:500 whereas the ratio of medical doctors to population is 1:40 000 . For millions of people in rural areas, native healers therefore remain their health providers [10].

In some countries such as Singapore and the Republic of Korea where the conventional health-care system is quite well established, $76 \%$ and $86 \%$ of the respective populations still commonly use traditional medicine [11]. Use of traditional and complementary medicine as complementary therapy is common in developed countries where the health system structure is typically well developed, e.g. North America and many European countries [9].

Achieving universal health coverage (UHC) has been set as one of the overarching goals in WHO's 12th General Programme of Work 2014-2019 [12]. In middle and low income countries, health insurance has emerged as a key instrument in health financing reform to achieve universal coverage [13].

Indonesia has held a universal health insurance program (universal health insurance) since 2014. The Government of Indonesia established a legal entity, the Health Social Security Administration Agency (BPJS) to organize a Health Insurance program. Through the National Health Insurance Program, it is hoped that all Indonesians are protected by a complete, fair and complete health Insurance [14].

Health insurance is found to increase the probability of seeking care and reducing delays. However, the probability, timing of seeking care and choice of providers varies across the insurance members [13].
Multivariate analysis showed that that gender, age group, employment status, knowing about the availability of health care, and Affordability of transportation costs to health care as dominant factors related to used of traditional health care. Compared with those who were male, those were female had 1.09 more likely to used of traditional health care [odds ratio adjusted $(\mathrm{ORa})=1.09 ; 95 \% \mathrm{CI}=$ 1.04 to 1.14]. Household who had low education level had 1.10 more likely to used of traditional health care (ORa $=1.10 ; 95 \%$ $\mathrm{CI}=1.03$ to 1.18 ). Household who were privat employees had 1.33 more likely to used of traditional health care $(\mathrm{ORa}=1.33 ; 95 \%$ $\mathrm{CI}=1.25$ to 1.41 ). Household who had high economic level had 1.31 more likely to used of traditional health care $(\mathrm{ORa}=1,31 ; 95 \%$ $\mathrm{CI}=1,23$ to 1,41 ). Furthermore, household who knowed about the availability of health care had 1.44 more likely to used of traditional health care $(\mathrm{ORa}=1,44 ; 95 \% \mathrm{CI}=1,29$ to 1,60$)$.

There are many differences between individual countries and regions to use traditional and complementary medicine. Some studies have shown that individuals choose traditional and complementary medicine for various reasons, including an increased demand for all health services, a desire for more information leading to an increased awareness of available options, an increasing dissatisfaction with existing health-care services, and a rekindled interest in "whole person care" and disease prevention. In addition, traditional and complementary medicine recognizes the need to focus on quality of life when a cure is not possible [9].

Social, cultural, and political values, as well as socioeconomic factors, influence T/CAM use in industrialized Societies [15].

In developing Countries, the affordability, availability, and Cultural familiarity of traditional medicine, as well as family influence contribute to the continued Ude of traditional medical providers and medicines [16].

In the last decade, across all types of utilization patterns, there has been an increase in selfhealth care as consumers choose to be more proactive about their own health. Many consumers turn to T\&CM products and practices on the assumption that "natural means safe", which is not necessarily true [17]. 


\section{CONCLUSION}

This study identified the dominant risk factors that related to use of traditional health care in the era health insurance in Indonesia. Subjects who were female, aged 46-65 years old, self-employed workers, aware of the availability of health services, affordable for transportation costs to health facilities were more likely to use traditional health care.

\section{ACKNOWLEDGMENT}

The author wishes to thank Dr. Siswanto for allowing to use data of 2018 Riskesdas..

\section{REFERENCES}

[1] Ministry of Health of the Republic of Indonesia. Law of the Republic of Indonesia Number 36 of 2009 concerning Health. RI Ministry of Health 2009.

[2] Delima, Widowati L, Astuti Y, Siswoyo $H_{\text {, }}$ Gitawati R, Purwadianto A. Overview of Practices on the Use of Herbal Medicine by Doctors in Six Provinces in Indonesia. Health Researcher Bul. 2012; 40 (3): 10922.

[3] President of the Republic of Indonesia. Republic of Indonesia Government Regulation Number 103 of 2014 concerning Traditional Health Services. 2014.

[4] Hasanah SN, Widowati L. Herbal Medicine in Tumor / Cancer Patients as Herbal Complementary Therapy as Complementary Therapy for Tumors / Cancer Patients Indonesia is a country with a very high burden of state funding. if there is a big progress from. J Pharmacy Indonesia. 2016; 6 (1): 49-59.

[5] Ministry of Health of the Republic of Indonesia. Law of the Republic of Indonesia Number 36 of 2014 concerning Health Workers. 2014.

[6] PPSDM Health Ministry of Health of the Republic of Indonesia. Health HR data that is utilized in Health Service Facilities (Fasyankes) in Indonesia [Internet]. RI Ministry of Health. 2019. Available from: http://bppsdmk.kemkes.go.id/info_sdmk/inf o/index?rumpun $=12$.

[7] National Institute for Health Research and Development. Final report of national basic health research 2013. Ministry of Health of
Indonesia. Jakarta; 2013.

[8] National Institute for Health Research and Development. Final report of national basic health research 2018. Jakarta; 2019.

[9] World Health Organization. WHO Traditional Medicine Strategy 2014-2023 [Internet]. World Health Organization. 2013. Available from: http://apps.who.int/iris/bitstream/10665/92 455/1/9789241506090_eng.pdf?ua $=1$

(Accessed 09.09.2016)

[10] Abdullahi A. Trends and Challenges of Traditional Medicine in Africa. African J Tradit Complement Altern Med [Internet]. 2011 Jul 15;8(5S):115-23. Available from: http://www.ajol.info/index.php/ajtcam/artic le/view/67959

[11] World Health Organization. The regional strategy for traditional medicine in the Western Pacific (2011-2020. Manila (Philippines); 2012.

[12] World Health Organization. Draft thirteenth general programme of work 2019-2023. 2018;(April 2018):50. Available from: https://www.who.int/about/what-wedo/gpw-thirteen-consultation/en/

[13] Chomi E, Mujinja PG, Enemark U, Hansen K, Kiwara A. Health care seeking behaviour and utilisation in a multiple health insurance system: does insurance affiliation matter? Int J Equity Health [Internet]. 2014;13(1):25. Available from: http://equityhealthj.biomedcentral.com/arti cles/10.1186/1475-9276-13-25

[14] President of the Republic of Indonesia. Presidential Regulation of the Republic of Indonesia Number 12 of 2013 concerning Health Insurance. 2013.

[15] Ong C-K, Petersen S, Bodeker GC, Stewart-Brown S. Health Status of People Using Complementary and Alternative Medical Practitioner Services in 4 English Counties. Am J Public Health [Internet]. 2002 Oct;92(10):1653-6. Available from: http://ajph.aphapublications.org/doi/10.210 5/AJPH.92.10.1653

[16] Bodeker G, Kronenberg F. A Public Health Agenda for Traditional, Complementary, and Alternative Medicine. Am J Public Health [Internet]. 2002 Oct;92(10):1582-91. Available from: http://ajph.aphapublications.org/doi/10.210 5/AJPH.92.10.1582 
[17] World Health Organization. Guidelines on developing consumer information on proper use of traditional, complementary and alternative medicine. Cambridge; 2004. 